\title{
FRASEOLOGISMIDE SEMANTILISE TEISITITÕLGENDAMISE VÕIMALIKKUSEST
}

\section{Anneli Baran}

\begin{abstract}
Ülevaade. Artiklis käsitlen fraseoloogiat, leksikoloogiaga tihedalt seotud valdkonda. Enamasti räägitakse fraseologismide mõistmisega seonduvatest raskustest seoses mitteemakeelse kõnelejaga. Ent ankeetküsitlus kahe eestikeelse kooli vanemate klasside õpilaste fraseoloogiaalasest teadmusest osutas, et eeldatavalt üldtuntud väljendid - vähem või rohkem idiomaatilised fraseologismid ei pruugi seda olla keele noorema kõnelejaskonna jaoks. Küsitlus näitas ilmekalt, et fraseologismide mõtestamises-kasutamises on toimunud mõningad muutused, mis on eelkõige seotud kas väljendi tähenduse ülekantuse mittemõistmisega, st otsese tõlgendamisega või põhisõnast ajendatud assotsiatsioonide alusel teisititõlgendamisega.*
\end{abstract}

Võtmesõnad: semantika, fraseoloogia, väljendid, ankeetküsitlus, eesti keel

\section{Sissejuhatuseks}

Fraseoloogiliste väljendite semantiline mitmepalgelisus on nähtus, mis fraseoloogiaga tegelejat kõige enam paelub. Fraseologismid ei kuulu iseenesest aga keele nende elementide hulka, mida ilmtingimata peaks tundma ja valdama (vrd sõnavaraalane $v$ s. fraseoloogiaalane kompetents), samas on nad suurepärased vahendid keele ilmestamiseks. Tegeledes pikemat aega eesti kõnekäändude ja fraseologismide andmebaasis (EKFA) sisalduva materjaliga, ${ }^{1}$ võib kergelt tekkida ettekujutus, et see aines on midagi, mis omab kohta ka tänapäeva aktiivses keelekasutuses. Tegelikult on tõenäolisem olukord, mida iseloomustab suurepäraselt tsitaat Delfi-blogist, kus arutletakse fraseologismide tõlkevastete üle:

Ja muidugi on eestikeelsed lahedad vasted ka olemas, võtame näiteks "nagu tuhat ja tuline" või "püksid sõeluvad püüli”. Oh jah, kahju kohe, et neil on selline "Eesti rahva ennemuistsete juttude" maik man. (Delfi.blog 2006)

\footnotetext{
* Artikkel on kirjutatud sihtfinantseeritava teadusteema 0032472 s03 "Eesti ja teiste rahvaste folkloor: pärimus, identiteet ja globaliseerumine" raames.

1 Tegemist on Eesti Kirjandusmuuseumi koosseisu kuuluva Eesti Rahvaluule Arhiivi laekunud materjaliga, mille digiteeritud versioon on kõigile huvilistele vabalt kättesaadav EKM-i folkloristika osakonna kodulehel aadressil http:// www.folklore.ee/justkui/ (24.09.2007)
} 
Seega kaldutakse vanu kinnistunud väljendeid pidama millekski vanamoeliseks ning pigem välditakse nende kasutamist.

Fraseologismi mõistesse on kätketud ühe olulisema erijoonena, et tegu on n-ö keelelise valmismaterjaliga. Sellest lähtuvalt võib esitada terve rea küsimusi: kas fraseologismi tähendust tulebki mõista staatilisena; kas nn fraseologismi algne/ algupärane tähendus on see tegelik ja ainuõige; kas fraseologismi tähendus võib varieeruda; kui kaugele võib see varieeruvus ulatuda; kas tavapärasest hälbivas tähenduses mõistmine või kasutamine on valekasutus?

Soovides välja selgitada mõningate fraseoloogiliste väljendite tuntust ja tegelikku aktualisatsiooni, on kõige hõlpsam võimalus teha seda Interneti vahendusel - on-line-väljaannete kommentaarikülgedel, kodulehtedel, veebipäevikutes jm sisalduva põhjal. Kuigi vanasõnade- ja fraseologismidealase teadmuse uuringud eri keelte kõnelejaskonna seas on üldlevinud, puuduvad Eestis tänini sellelaadsed korralikud (täpsemalt laiaulatuslikud) küsitlused, ning fraseoloogide endi poolt läbiviidute kohta puuduvad andmed hoopiski. Pidades fraseoloogilisi keeleüksusi millekski, mis alluvad keelekasutuses nn automaatsele tuvastamisele ja töötlemisele, teisisõnu millekski, mis omavad kindlat kohta keelekasutaja mentaalses leksikonis, tuleb arvestada, et tegelikult on uuringud selles valdkonnas veel napid ja alles päris viimasel ajal hoogustumas.

Otsustasin küsitluse viia läbi nooremate keelekasutajate - gümnaasiumiõpilaste - seas. Vanusemäära tingis vanasõnauurijate - peaasjalikult saksakeelses keskkonnas tegutsevate - poolt kindlaks tehtud tõsiasi, et just vanuseks 16-18 on inimene omandanud vanasõnadealase teadmuse (Baur, Chlosta 1994: 3). Seega lähtutakse inimese keelelise ja kognitiivse võimekuse aspektist. Hõlbus oleks laiendada seda teesi ka fraseologismidele, sest fraseoloogiat laiemas tähenduses käsitledes kuuluvad siia ka vanasõnadega tihedas seoses olevad kõnekäänud (lähemalt vt Baran 1999 ja Õim 2004). Küsitlusega soovisingi saada muuhulgas vastust vanuselise aspekti paikapidavusele, kaldudes küll arvama, et pigem kujuneb mingitasemeline fraseoloogiaalane teadmus välja siiski varem, sõltudes rohkem iga konkreetse keelekasutaja taustast. V. Jenenšeki erinevate keelte peal tehtud uuringud näitavad, kuidas juba lasteaiaealised lapsed on suutelised fraseologisme mõistma ja kasutama (Jenenšek 2006: 138). Tegemist on lihtsalt keeleüksustega, mida omandatakse pidevalt, st see protsess ei lõppe mitte teataval vanuseastmel, vaid on dünaamiline. Seetõttu on selge, et nooremad keelekasutajad tunnevad tunduvalt vähem fraseologisme kui vanemad. ${ }^{2}$ Samas tuleb ka meeles pidada, et fraseologismide tundmisel on omad erijooned.

Küsitluse eesmärgiks oli eelkõige proovida välja selgitada, kas kinnistunud keelendid omavad üldse kohta tänaste kooliõpilaste sõnavaras (leksikaalases teadmuses) ja kui omavad, siis kuidas on muutunud nende väljendite kasutus. See omakorda annaks aimu küsitletavate nn taustteadmistest ehk entsüklopeedilisest teadmusest. Fraseologismid on oma olemuselt selgelt mitmetähenduslikud. Küsimus ei ole aga üksnes keeleüksuse tajumises teljel mittekujundlik-piltlik/kujundlik. Kinnistunud väljendite kontiinum on astmeline (või siis radiaalne, st tuuma ja perifeeriga üksus), st nad on ka erineval määral motiveeritud ning sellest tingituna erinevalt mõistetavad/tõlgendatavad ning erinevate keelekasutajate jaoks erineval määral läbipaistvad. Eeldatavalt peaksid küll teatud fraseoloogilised väljendid

2 Suurepäraseks näiteks väikesearvulise kasutajaskonnaga keele fraseoloogia alalt on Natalia Filatkina monograafia, kes on sarnaselt eesti keelele väikese kõnelejaskonnaga, nimelt letseburgi fraseoloogiat uurides läbi viinud ka põhjalikke küsitlusi, sh koolinoorte hulgas, ning on sedastanud, et fraseologismide tundmine ja tegelik kasutamine ei ole päris üksüheses suhtes, st neid fraseologisme, mida tuntakse, on märkimisväärselt rohkem kui on kombeks reaalselt kasutada (Filatkina 2005: 89). 
(tuuma esindavad elik tuntumad) alluma hõlpsamalt intuitiivsele tõlgendamisele kui teised. ${ }^{3}$

Nii Dmitri Dobrovolski (1997: 46 jj) kui Eckhard Roos (2001: 269 jj) on osutanud asjaolule, et nende väljendite, mille otsene tõlgendus on vastuolus kuulaja teadmusega, tõlgendus välistatakse. Sellised ütlused on tugeva piltlikkusega ning enamasti vastuolus tegelikkusega (või meie teadmistega sellest tegelikkusest) ning läheneb absurdile. Seega nad ei ole semantiliselt mitmetähenduslikud, kuna ei võimalda kahesugust tõlgendust.

Viimasel ajal kohtab üha sagedamini fraseoloogiaalastes sõnavõttudes ja kirjatükkides mõistet esilduvus (ingl salience), veelgi täpsemalt astmeline esilduvus (ingl graded salience), ning seda seoses fraseologismi semantikaga (vt Hallsteinsdóttir, Farø 2006). Selle kohaselt ei aktiviseeru kinnistunud keelendi otsese tähenduse kõrval veel teinegi analoogne tegevus, milleks on fraseoloogilise tähenduse aktiviseerimine mentaalses leksikonis, vaid esmalt aktiviseeritakse teada olev ehk tuntud tähendus (ning seda sõltumata kontekstist). Ning alles seejärel, kui see tähendus ei sobi, asutakse konstrueerima teisi tähendusi. Salientsuse-teooria eestkõneleja Rachel Giora on rõhutanud idioomide puhul just asjaolu, et nende idiomaatiline tähendus ongi salientne tähendus ning aktiviseeritakse kiiremini kui muud võimalikud tähendused (Giora 2003: 19).

Tegelikult ei ole sellises lähenemises midagi uut, sest juba aastaid varem on Raymond Gibbs oma psühholingvistiliste eksperimentide tulemusena sedastanud, et inimestel ei kulu idioomide, kaudse kõne, sarkasmi ja metafoori kujundliku tõlgenduse mõistmiseks/töötlemiseks mitte sugugi rohkem aega (ning mõningatel juhtudel isegi vähem) kui otsesest tähendusest arusaamiseks. Kujundliku keelekasutuse korral ei eelne tõlgendamisele mingit sellesama lausungi otsese tähenduse analüüsi etappi. R. Gibbs järeldas ka, et taolist käitlemist toetab kontekst, mis toob vastavad tähendused esile ehk muudab salientseks. Kusjuures konteksti all ei pea R. Gibbs silmas mitte üksnes kitsalt keelelist, n-ö tüüpilist kasutuskonteksti, vaid kontekstuaalset raamistikku entsüklopeedilise teadmuse näol (Gibbs 1989: $247 \mathrm{jj})$.

\section{Küsitlus eesti koolinoorte seas}

Selgitamaks välja just vanimate, $n$-ö põlisteks puhteestilisteks peetavate fraseoloogiliste väljendite tegelikku tuntust, võtsin küsitlusse väga vanad väljendid - varaseimad fikseeringud 18. sajandi algusest (paari erandiga hilisemast ajast). Valikut raskendas EKFA-s sisalduva materjali rohkus ning ligi 170 ooo teksti seast 35 väljendi selitamine ei ole n-ö kergete ülesannete killast. Valikul sai määravaks ühelt poolt väljendi ere kujundlikkus (subjektiivne kriteerium) ja teisalt populaarsus läbi aegade (objektiivne kriteerium), sellest peaks andma tunnistust tema esinemus nii EKFA-s kui ka fraseoloogiasõnaraamatus (FS), kusjuures EKFA esinemuse puhul olid kriteeriumiks kõrge üleskirjutuste arv ja lai geograafiline esinemus mitte ainult 18.-19. sajandi, vaid ka 20. sajandi lõpul (v.a kaks väljendit: retooriline küsimus Kas oled näinud kellaga siga?, mis esineb peamiselt Lõuna-Eestis, ning väljend üks silm vaatab tasku, teine taeva, mis tuleb ette üksnes Saaremaal (laiemalt on tuntud

3 Kognitivistlikust vaatevinklist on igasugused väljendid vähem või rohkem läbipaistvad ning täiesti läbipaistma- 
üks silm vaatab kirikutorni, teine lihakarni ja üks silm vaatab silku, teine leiba)). Enamik küsitud väljendite varaseimatest allikatest, mis on esindatud EKFA-s, on ühtlasi eesti kirjakeele ajaloo uurimise olulisemad allikaid: A. T. Helle "Kurtzgefasste Anweisung zur Ehstnischen Sprache.." (1732), A. W. Hupeli "Ehstnische Sprachlehre für beide Hauptdialekte..” (1780), J. F. Helleri käsikirjaline (lõuna)eesti-saksa sõnaraamat (koostatud tõenäoliselt ajavahemikus 1823-1841), S. H. Vestringi eesti-saksa käsikirjaline sõnaraamat "Lexikon Esthonico Germanicum" (1720-ndad), F. J. Wiedemanni koguteos "Aus dem inneren und äusseren Leben der Ehsten" (1876), J. V. Jannseni koostatud Sannumetoja I-VII (1848-1860).

Miks aga peaksid vanad väljendid üldse veel aktiivses kasutuses olema? Siinkohal jagan seisukohta taani fraseoloog Ken Farøga, kes rõhutab tõsiasja, et fraseoloogilisi väljendeid ei kasutata mitte niivõrd kõnestrateegilistel eesmärkidel, vaid pigem seepärast, et nad sobivad kontekstiga või on mnemotehnilistel põhjustel teadliku kõneleja jaoks hõlpsasti haaratavad (Farø 2006: 60).

Küsitletavateks olid kahe gümnaasiumi õpilased vanuses 16-18, küsitletuid kokku 147: Kuressaare Gümnaasiumis (KG) (X ja XII kl) 86: 33 noormeest (M) ja 53 neidu (N); Tartu Miina Härma Gümnaasiumis (MHG) 61 (Xja XII kl): 23 noormeest ja 36 neidu, 2 isikuandmeteta. Küsitlus oli anonüümne, oluliseks pidasin soolist ja vanuselist aspekti, mistõttu palusin küsitletavatel kindlasti märkida oma sugu ja vanus. Kaks Eestimaa eri otsas paiknevat kooli (kuhu tullakse ka mujalt maakonnast või ka - nagu Tartu kooli puhul - teistest lähematest maakondadest) sai valitud eesmärgiga välja selgitada murdetaustalt (kuivõrd selline tegur tänases keelesituatsioonis üldse rolli mängib) võimalikult erinevate keele kõnelejaskondade tegelikke erinevusi fraseoloogilise ainese tundmise osas. Seetõttu saigi küsitlusse lülitatud ka eelpool mainitud väljendid, mis kõnekäändude ja fraseologismide andmebaasi põhjal omavad peaasjalikult piirkondlikku levikut. Samuti pidasin küsimustikku koostades oluliseks mitte piirduda pelgalt suletud tüüpi jah/ei-küsimusega (tunnen / ei tunne), vaid jaatava vastuse korral soovisin ka lähemat selgitust fraseologismi tähenduse ja kasutamissituatsiooni kohta (avatud küsimus).

Küsitluses esitatud väljendite omaaegset tuntust ja tegelikku tundmist illustreerib tabel 1, kus võib näha kõrvutavalt kahesuguseid andmeid: väljendi järel teises veerus on sellesama väljendi koht Arvo Krikmanni poolt koostatud loendis "100 tuntumat eesti kõnekäändu" (Krikmann 1997) - aluseks üleskirjutuste hulk EKFA-s, kolmandas veerus sisaldub küsitlusega laekunud jaatavate vastuste üldarv ning sulgudes vastused kooliti.

Tabel 1. Küsitletud fraseologismide nimistu nende tuntuse alusel

\begin{tabular}{|l|c|c|}
\hline \multicolumn{1}{|c|}{ Fraseologism } & $\begin{array}{c}\text { Koht A. Krikmanni } \\
\text { loendis }\end{array}$ & $\begin{array}{c}\text { Jaatavate vastuste üldarv } \\
\text { (KG + MHG) }\end{array}$ \\
\hline teeb sääsest elevandi & 52. & $147(86+60)$ \\
\hline ei lausu musta ega valget & - & $137(79+58)$ \\
\hline süda kukkus saapasäärde & 95. & $131(80+51)$ \\
\hline elavad nagu koer ja kass & 99. & $127(75+52)$ \\
\hline nüüd on vesi ahjus & 13. & $117(70+47)$ \\
\hline vaatab läbi sõrmede & - & $114(71+43)$ \\
\hline ei näe sõrmegi suhu pista & - & $109(63+46)$ \\
\hline
\end{tabular}




\begin{tabular}{|c|c|c|}
\hline käib nagu kass ümber palava pudru & 31. & $102(61+41)$ \\
\hline nagu juudi jõulupuu & - & $102(55+47)$ \\
\hline hunt lambanahas & - & $100(62+38)$ \\
\hline peenike peos & 86. & $99(58+41)$ \\
\hline üks jalg hauas, teine haua äärel & 11. & $96(57+39)$ \\
\hline elab peost suhu & - & $91(54+37)$ \\
\hline see on hoopis teine tubakas & - & $83(49+34)$ \\
\hline vorst vorsti vastu & - & $81(42+39)$ \\
\hline ega sa klaassepa poeg ole & 39. & $73(46+27)$ \\
\hline kõrvatagused alles märjad & 84. & $67(35+42)$ \\
\hline must kass on vahelt läbi jooksnud & 83. & $55(35+20)$ \\
\hline pane või hambad varna & 18. & $52(34+18)$ \\
\hline segi nagu Kört-Pärtli särk & - & $42(14+28)$ \\
\hline püksid sõeluvad püüli & 33. & $41(23+18)$ \\
\hline üks silm vaatab tasku, teine taeva & 38. & $35(23+12)$ \\
\hline mitu tuult jalge all & - & $32(22+10)$ \\
\hline ega mu suu pole seinapragu & 60. & $31(24+7)$ \\
\hline tulid nagu tuld tooma & 52. & $21(18+3)$ \\
\hline küll tema teab, kus kivi all vähid on & - & $19(12+7)$ \\
\hline koergi ei haugu takka & - & $14(9+5)$ \\
\hline suurte kõrvadega supilontrus & - & $13(9+4)$ \\
\hline lammas läheb vähi käest villa küsima & 21. & $13(9+4)$ \\
\hline mõni mõis või ahjutäis vorste & - & $12(9+3)$ \\
\hline ei vea villast lõngagi katki & - & $12(2+10)$ \\
\hline nagu hobuse unenägu & - & $11(9+2)$ \\
\hline nüüd on konn mätta otsas & 9. & $11(7+4)$ \\
\hline võta silm näppu & - & $6(2+4)$ \\
\hline kas oled näinud kellaga siga? & - & 0 \\
\hline
\end{tabular}

Kuna küsitlus oli piiratud ajaliselt ühe koolitunniga, esitasid õpilased pigem tähenduste seletused kui kasutuse iseloomustused. Harvadel juhtudel täpsustati: ise ma seda ei kasuta, kasutan harva, kasutan sïs kui... Sellised metakommunikatiivsed kommentaarid on eelkõige põhjendused mitte/harvakasutamise kohta.

Märkimisväärseid teadmiserinevusi koolide vahel välja ei tulnud, sh murdelise tagapõhjaga väljendite juures, mistõttu saab pigem rääkida ühistest joontest ning suundumustest. Samas tuleb arvestada, et tegemist on esialgse katsega selles vallas ning järeldustesse tuleb suhtuda teatava mööndusega. Siiski saab välja tuua mõningad arvud, joonisel 1 on esitatud jaatavate vastuste suhe kahe kooli võrdluses.

Kuressaare Gümnaasiumi 86-st õpilasest vastasid jaatavalt - st tunnen küsitud fraseologismi - rohkem kui pooltele 24 õpilast, Miina Härma Gümnaasiumi 61-st 17 õpilast. Jah-vastuseid anti kõige enam 11-17 korral. Keskmiselt tunti 14 (KG-s 
14,1, MHG-s 14,9) väljendit 35-st, mis teeb alla poole väljenditest. N-ö parimaid tundjaid (20-26 fraseologismi 35-st) oli KG-s $15(12 \mathrm{~N}+3 \mathrm{M})$, MHG-s $7(5 \mathrm{~N}+2 \mathrm{M})$, seega ühes napp kolmandik, teises veelgi vähem.

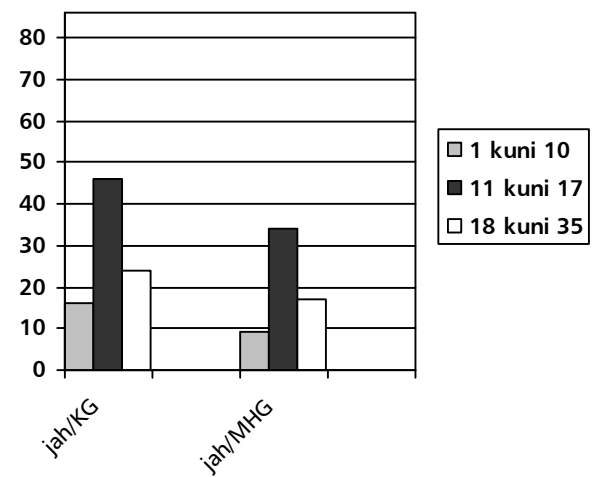

Joonis 1. Jaatavate vastuste suhe koolide võrdluses

Jaatavate-eitavate vastuste vahepeale jäid minu poolt küsimärgistatud vastused, mida analüüsingi lähemalt järgnevas peatükis. Selliste n-ö äraspidiste tähendusseletuste koguarv ei ole küll suur: MHG 2135 vastusest 102 ja KG 3010 vastusest 113. Keskmiselt teeb see mõlema kooli puhul 2,9-3,2 väljendit 35-st. Ent just sellised vastused huvitavad fraseoloogi iseäranis, sest näitavad, kuidas mõtestatakse väljendit juhul, kui seda tegelikult ei tunta. Huvitava iseärasusena kerkib esile tõsiasi, et enam andsid selliseid vastuseid noormehed, keda vastajate seas oli tütarlastest vähem.

Järgnevas võtan vaatluse alla just sellised tähendusseletused, mis hälbivad mõnevõrra fraseologismi tavatähendusest. Fraseologismi põhitähendusena esitan fraseoloogiasõnaraamatus (FS) fikseeritu või seal mitteesinemise või mõnevõrra erineva esinemuse korral eesti kõnekäändude ja fraseologismide andmebaasis (EKFA) sisalduva.

\section{Fraseologismide tähenduste seletused}

\subsection{Väljendi seletamine teise väljendiga}

Küsitlusest ilmnes, et mõnede fraseologismide tähenduse seletamiseks kasutatakse teist väljendit ehk kujundlikku ütlemist. Tegemist on psühholingvistiliselt huvitava seigaga - ühe väljendiga seostub teine samas/lähedases tähenduses kasutatav väljend või värvikas üksiksõna. Sellist omalaadset koosesinemist võib vaadelda kui mentaalset võrgustikku, mis seostub ühe ja sama kontseptuaalse/mõistelise valdkonnaga või milles üks väljend toimib mõjurina, kutsudes esile/aktiviseerides muu selle nn mõjuriga mälus seonduva skriptina määratletava ilmingu. ${ }^{4}$ Dmitri Dobrovolski (1997: 36) on osutanud asjaolule, et väljendi töötlemist ei määragi mitte omandatud teadmised, vaid teatud kognitiivsed süvastruktuurid. ${ }^{5}$ Sageli võib selliste seletavate väljendite puhul täheldada ka struktuurilist sarnasust. Järgmise

4 Kognitivistikast pärinev mõiste skript (nt Wierzbicka 1999) on keskne huumoriteoorias (Victor Raskini skriptipõhine naljateooria), Eestis on selle (stiimul)sõna ümbritsevat semantilist infot märkiva termini kohta põhjalikult kirjutanud A. Krikmann monograafias "Koestler, Raskin, Attardo ja teised: lingvistiliste huumoriteooriate uuemaist areguist" (2004)

${ }_{5}^{5}$ D. Dobrovolski peab siinkohal silmas varieerimist analoogia alusel, mitte normi järgimist. 
viie väljendi puhul kasutati küsitluses kõige sagedamini tähenduse lahtiseletamisel teist samatähenduslikku väljendit.

(1) segi nagu Kört-Pärtli särk 'kõik on pilla-palla laiali', 'suur segapudru', 'tohuvabohu' (FS 'segamini, sassis')

(2) ei lausu musta ega valget 'vait kui sukk', 'ei ütle head ega halba', 'ei ütle ei nii ega naa' (FS 'mitte ühtegi sõna, mitte midagi ütlema')

(3) ei näe sõrmegi suhu pista 'kottpime', 'pilkane pime', 'pime kui öö' (FS 'väga pime')

(4) üks jalg hauas, teine haua äärel 'vaagub elu ja surma vahel', 'hinge heitmas', 'surmasuus', 'ühe jalaga hauas', 'kõigub elu ja surma vahel', 'muldvana', 'nagu noateral' (FS 'õige vana, kõrges eas, surmale lähedal')

(5) nü̈̈d on vesi ahjus 'pill on lahti', 'omadega plindris', 'karistus soolas', 'häda kaelas' (FS 'kellelgi on häda käes, keegi on täbarasse olukorda sattunud')

\subsection{Väljendi mõistmine üksnes otseses tähenduses}

Enim huvipakkuvateks pean fraseoloogina siiski küsitluses esitatud nn valesid seletusi. Nende puhul tuleb arvestada, et väljendi tegeliku mittetundmise korral (st vastates jaatavalt) võidi üritada seda tõlgendada ehk remotiveerida, kas siis otseselt või mingite assotsiatsioonide alusel. Fraseologismi puhul on tähtsaim semantiline aspekt, täpsemalt fraseoloogilise tähenduse ja otsese tähenduse vahekord. Kahe tähenduse vastukäivus, ühtesobimatus, vastuolu tingib väljendi (semantilise) idiomaatilisuse. Ilmneb, et seda idiomaatilisust ei pruugita enam tajuda elik ära tunda, st väljendid võivad keelekasutaja jaoks olla läbipaistmatud ning väljendi mõtestamine võetakse ette analüütiliselt. Seega on väljendi puhul esilduvaks tähenduseks otsene tähendus.

(6) vaatab läbi sõrmede 'ei taha hästi vaadata', 'hirmus, hirm', 'piilub', 'kartlik' (FS 'millelegi taunitavale reageerimata jätma')

(7) pükssid sõeluvad püüli 'kulunud püksid', 'pükstes nii palju auke, katki', 'katkised püksid' (FS 'kartma')

(8) ega sa klaassepa poeg ole 'ega sa õrnake pole', 'ettevaatlik', 'teeb kõike väga õrnalt ja ettevaatlikult', 'purunema', 'õrnake, pussy' (FS 'öeldakse valguse ees seisjale')

(9) kõrvatagused alles märjad 'on ujumas käinud', 'alles sündinud', st 'kiirustamine' (FS 'noor ja kogenematu')

(10) ei näe sõrmegi suhu pista 'ta on pime' (FS 'väga pime')

(11) peenike peos 'midagi on peos' (FS 'raskes olukorras) 


\subsection{Väljendi tähendus on teisenenud}

Järgneva neljateistkümne väljendi puhul joonistus samalaadsete vastuste arvukuse põhjal selgelt välja, et tähenduses on toimunud semantiline nihe. Need on väljendid, mille tähendus n-ö kumab läbi (osaliselt või täielikult motiveeritud), mistõttu tõlgendamisel tuginetakse salientsele otsesele tähendusele või assotsiatiivsetele seostele. Erinevalt eelmise rühma väljenditest võib siia paigutatuid vaadelda kui tavatähendusest mõnevõrra hälbivaid tähendusvariante (milledest mõned on tavatähendusele lähemal kui teised; selle vahemaa hindamine on aga loomulikult suuresti subjektiivne).

Võimaluse korral kaasan näitestikku ka küsitlusse võetud väljendiga samas või lähedases tähenduses kasutatud Interneti-näiteid, seda peamiselt eesmärgiga näidata selliste väljendite aktuaalsust keele väljenduslikumaks muutmise vahendina ka tänapäeval (keelenäited pärinevad viimasest viiest aastast). Nagu näidetest näha, võidakse fraseologismidega ringi käia üsnagi vabalt. Samas võiks oskust käidelda oma olemuselt klišeelist fraseologismi mänglevalt kui näidet keele suurepärasest valdamisest.

\section{(12) ei vea villast lõngagi katki}

FS -; EKFA 'laisk'

'nõrk', 'pole jõudu', 'ei ole tugev', 'õrn', ‘ei ole võimeline kellelegi liiga

tegema', 'saamatu millegi suhtes'

Kooliõpilaste seletused tuginevad otseselt puhtfüüsilisel omadusel - keegi on sedavõrd jõuetu, et ei ole võimeline isegi kaalult nii kerget asja nagu lõng katki tegema.

\section{(13) must kass on vahelt läbi jooksnud}

FS 'kellegi vahel on lahkhelid, keegi on omavahel tülli või pahuksisse läinud'

Kooliõpilaste tähenduseseletuste aluseks on pigem uskumusest väljakasvanud nn argiarvamus - kui must kass üle tee läheb, siis tuleb õnnetus. ${ }^{6}$

'must kass toob paljude arvates halba õnne, kasutatakse kui tülis on keegi', 'kõik läheb halvasti', 'on õnnetus juhtunud', 'kõik läheb mingil põhjusel untsu', 'häda ja tüli'

Tüli võibolla ei tulegi, aga must kass jookseb meie vahelt läbi küll. (Pere ja Kodu 2007)

(14) еga тu suu pole seinapragu

FS 'keegi tahab ka midagi maitsta, keegi tunneb ka millestki maitsvast rõõmu'

Tähenduseseletuste aluseks on pigem suu kui kõnelemiselund. Sellest on omakorda visualiseerides tuletatud kahetised tähendused: võrdluses suuga on seinapragu avausena miski, mis on a) pidevalt lahti nii nagu inimesel, kes ei suuda suud kinni pidada, või siis hoopis vastupidiselt b) miski, kust heli väljatulek on välistatud/piiratud:

${ }^{6}$ Vrd ka saksa fraseologismiga da ist die schwarze Katze zwischen gekommen 'will eine Sache gar nicht gedeihen, so sagt man deshalb' (Röhrich 1973). [Tölkes seal on must kass vahele tulnud 'öeldakse siis, kui asi ei taha kuidagi edeneda'.] 
a) 'lobamokk', 'mul on palju öelda', 'julgeb rääkida', 'pole vastusega kitsi', 'pole mõtet peale asja halvaksminekut möliseda, kui enam midagi nagunii päästa ei anna';

b) 'ega ta midagi välja ei räg̈gi, usaldusväärne', 'ega ta jutukas pole', 'ega ma niisama tühja juttu ei aja', 'kõike ei räg̈gita, rumalusi näiteks', 'seinapragu ei panda tähele ja seda ütleb tavaliselt inimene, kes tunneb, et temaga ei arvestata ega panda tähele'.

Korterite teema kohapealt peaks Atoneni suu küll seinapragu olema. (Postimehe kommentaarikeskus 2004)

Imbetsill postita vähem, sinu suu on sïn foorumis seinapragu, saa sellest lõpuks aru, sa seletad liiiga palju. (Freetime foorum 2007)

(15) pane või hambad varna

FS 'nälga jääma, nälgima'

Väljendit mõistetakse kui puhkama asumist või hoopiski millestki eksistentsiks vajalikust loobumist; viimasel juhul on tulemus traditsioonilise tähendusega võrreldes kaugemaleulatuvam, tähistades pigem paratamatut lõppu.

'sure ära', ‘tööd lõpetama, pooleli jätma midagi, surema', 'ehk lõpeta toiming, võrreldakse lõpu ehk surmaga', 'haige, hakkab surema', 'puhkama hakkamise plaan', 'sure või maha', 'väga vana', 'süüa enam ei ole, järelikult ei ole hammastel ka muud teha kui puhata (varnas)', 'ehk lõpeta toiming (võrreldakse lõpu ehk surmaga)'

Kui teha paar visiiti kihvatohtrijuurde, ongi kõik. Millest siis aga elada? Ega jää muud üle, kui hambad varna ja otse hauda.!!! (Kesknädal 2007)

(16) nagu hobuse unenägu

FS 'mõttetus, absurdsus'; EKFA 'vilets asi; rumal või inetu või pikaldane inimene; segane asi'

Antud väljendi puhul torkab silma, et sõnaraamatu tähendus on tunduvalt üldistatum kui EKFA-s fikseeritu. Samas näitavad nii kooliõpilaste tõlgendused kui Interneti kasutusjuhud, et pigem on tähendus analoogne EKFA-s leiduvaga:

a) 'suur uni', 'võid öelda inimese kohta, kes sulle kogu aeg järele käib', 'midagi mis on väga pikk, igav ning veniv', 'midagi väga pikka';

b) 'mingi kirju situatsioon, tegevusterohke'.

Ja õhu teekond mootoriruumis on pikk nagu hobuse unenägu. (Saabnet 2006)

Paratamatult tekib aga küsimus, milleks siis haridus üldse on, kui ametite loomulik hierarhia on segi nagu hobuse unenägu. (Delfi 2007)

(17) tulid nagu tuld tooma

FS 'korraks, lühikeseks ajaks kellegi poolt läbi astuma, kedagi väga põgusalt külastama' 
Seletuste aluseks on hoopiski tulega assotsieeruv tulekahju ning tuletoomise tegevuse all mõistetakse tule külge panemist, st hädaohtu kellegi poolt (a). Samas leidus üllataval kombel ka täiesti vastupidises, st positiivses tähenduses tõlgendusi (tuli kui valgus) (b):

a) 'tüli norima', 'tulid tülitsema', 'riidu norima', 'tulid nagu pahandust/õnnetust tooma/tegema', 'tulid vihaselt',

Heameelt teeb seegi, et minister ei tulnud vaid tuld tooma ja poliitloengut pidama, vaid leidis aega paar tundi kohalikku elu vaadata. (EPL 2007);

b) 'tulid head tooma', 'päästsid halvast'.

\section{(18) süda kukkus saapasäärde}

FS 'keegi hakkab kartma, lööb araks, kellelgi kaob julgus'

'süda murdus, kurb', 'inimene muutus õnnetuks', 'pettuma', 'langes suurde masendusse', 'hakkas häbi', 'šokiseisund', 'süda heldis'

Järjekordset massiivset ja argumenteerimata linnavaramü̈̈ki põhjendades ütles abilinnapea Aaviksoo, et toetas seda raske südamega. Uskuge mind, kõigile on näha, et süda on juba nii raske, et on vajunud saapasäärde. (Palts 2005)

Näide 18 on sellest, kuidas mõjus piltlik väljend võib omandada tähendusi, milles liigutakse mõisteliselt hoopis teistesse valdkondadesse (samas mitte ka ülemäära kaugelseisvatesse). Nii on siin tegu peamiselt inimese hingelise seisundi kirjeldamisega. Ka Internetist pärinev näide osutab ilmekalt, et süda võib liikuda allapoole vaid raskuse mõjul; raskelt mõjuv, rõhutud, löödud hoiak on aga seostatav pigem kurbusega. Tegemist on Lakoff-Johnsoni kõnepruugis orientatsioonimetafooriga: ÕNNELIK ON ÜLES, ÕNNETU/KURB ON ALLA (Lakoff, Johnson 1980: 15-16).

(19) suurte kõrvadega supilontrus

EKFA 'poisikeste omavaheline tögamissõna'; EKSS 'kirumissõna'

Tähenduseseletustes lähtutakse välimusest ning mõtestamise järgmine arenemisjärk, milleks on üldistav edasiarendus, puudub:

a) 'no lihtsalt kole', 'nii loll, et sarnaneb supikausile', 'tegemist on väga suure lontrusega', 'kõrvad välja veninud', 'kui väga suured kõrvad, et saaks suppi süüa';

b) 'kuuleb kõike pealt, ka seda mida poleks vaja', 'kuuleb kogu aeg asju pealt, võib jutte levitada'.

Erinevalt kooliõpilaste antud seletustest, ei ole Interneti-näited mitte inimkesksed, vaid väljendit kasutatakse pigem looma, täpsemalt koera kohta. Ka slängisõnaraamatust (EESS) leiab väljendi märksõna koer alt.

Üks supilontrus loivab sulle padja peale (muideks nad just hommikul õppisid kõndimise ära!) ning sikutab end küünte abiga su otsaesisele magama. Nii me siis magasime terve öö otsa. (Ussipesa 2005) 
Isiklikult kassid ei sümpatiseeri aga koeri armastan küll - endalgi üks spanjelist supilontrus. (Keskmaa 2004)

Supilontrus 'supisõbralik peni (eriti asjakohane ütlus, kui isend juhtub olema sündinud suurte laperdavate kõrvadega, mis iseenesest mõista alatasa supi sees tolgendavad)' (EESS)

\section{(20) hunt lambanahas}

FS 'malbusega oma kurje kavatsusi varjav inimene, vagurust teesklev kuri inimene'

Nii mitmegi seletuse taustaks on sümbolikeskne mõtlemine lambast kui arast loomast (a). Samas kui hundile omistatakse julgust, mis ei ole sugugi selle looma n-ö põhiomadus (pigem on selleks jultumus ehk häbematu julgus, mis on ka antud väljendi aluseks); võidakse ka - tõenäoliselt seda hästi tundvana - tavapärast tähendust originaalselt edasi arendada (b), sama kohtab ka Interneti-näidete puhul:

a) 'hirm', 'arglik'; 'tegelikult on julge isik, aga näitab vastupidist', 'väljast nõrk, seest tugev', 'teeb, et on julge, aga tegelikult on arg', 'julge, aga pole mille üle uhkustada';

b) 'mingi eriti tugev või lihtsalt kõva mees lööb araks', 'välimus tagasihoidlik, sisemus karm', 'näeb ilus välja, aga tegelikult sitt iseloom'.

Saatuslikuks saab hunt lambanahas, kus kiskja iseloom lópuks pealejääb. Kui koalitsioonilepe ka vormistatakse, saab sellele saatuslikuks ikkagi Laari leppimatus temale antud positsiooniga. (PM kommentaarikeskus 2007)

Itaallastest rääkides pakuks sellist hunt lambanahas valemit - võtad mittemidagiütleva kerega alfetta põhjale ehitatud sedaani ning varustada selle Alfa 24V 3,o V6-ga (tulemus - imehea kaalujaotusega võimas ning üsna tuima välimusega isend). (Auto24 2006)

Eriti tore on see, et neile paigaldatakse ls1(corvette) mootorit, mõnus hunt lambanahas. (Streetrace 2007)

(21) nü̈̈d on konn mätta otsas

EKFA 'uhke; suurustaja; vaese inimese kohta, kes on saanud teiselt varanduse, millega jõukalt elab; kui vihamees on saanud mõnele juhtivale kohale'

FS nagu konn mättal 'oma positsiooniga uhkeldav, suurustav inimene'

Küsitud väljend sellisel kujul fraseoloogiasõnaraamatus puudub, tõenäoliselt ongi rohkem tuntud võrdlusevormilisena (mida osutasid ka Interneti kasutusjuhud). Ka väljendi vähene tuntus kooliõpilaste seas on arvatavasti sellega seletatav. Nagu mõningatest õpilaste seletustest nähtub, võidakse väljendit mõista ka positiivses tähenduses - kõrgemale kohale (= positsioonile) jõudmine kui märk edenemisest, olukorra muutumine paremuse suunas (a). Sellisel juhul on äratuntav selle taga olev orientatsioonimetafoor HEA ON ÜLAL / HALB ON ALL. Teisalt aga antakse ka täiesti vastupidine seletus, mis sarnaselt fraseoloogiasõnaraamatu tähendusele on küll negatiivselt märgistatud, ent käib pigem olukorra kui inimese kohta (b): 
a) 'isik, kes tunneb ennast kuskil hästi ja turvaliselt', 'kõik on korras, valmis', 'eesmärk saavutatud';

Peale väheste visionääride, kes oma ambitsioone liigselt ei reklaami, on suurel osal meist kombeks elada omi asju ajades nagu konnad mättal, kes, tundes küll hästi oma lompi, on kogu maastiku suhtes üsna ükskõiksed. (Diplomaatia 2005)

On tavaline, et see, kes oma raha rahandusministrilt või Rïgikogult on välja võidelnud, istub nagu konn mätta otsas ja peab seda raha enda omaks. (Kesknädal 2002)

b) 'konn kuival', 'häda majas'.

(22) mitu tuult jalge all

FS 'kellelgi on palju tegemisi, ettevõtmisi, sündmusi ees'

Suure hulga tõlgenduste aluseks on pigem ettekujutus sihitust ja kiirest liikumisest (vrd kadus kui tuul) (a). Mõned ülekantud tähendused (b) näivad tuginevat assotsiatiivsetel seostel muude väljenditega, nagu kust tuul, sealt meel.7 Omaette tähendusena eristasin seletuse, milles tuuakse sisse muutusi märkiva uute tuulte n-ö edasiarendusena paremad tuuled (c). Sõnaühend mitu tuult on aga üsna tõenäoliselt juhtinud seletusi, mis seonduvad hoopiski väljendiga mitu rauda tules 'mitut võimalust alal hoidma' (d):

a) 'põgenema', 'jookseb hästi kiiresti', 'väga kiire', 'ei suuda paigal olla, peab kogu aeg liikuma', 'reisib pidevalt', 'pidevas reisimises';

b) 'käib igal pool vastavalt sellele, kuidas tuju on', 'mitu mõtet, mida teha, aga ei ole veel otsustatud', 'palju mõtteid peas';

c) 'läheb sinna, kus paremad tuuled';

d) 'mitmes kohas käsi sees', 'on seotud mitme asjaga, nt mees semmib kahega korraga', 'käib mitme eidega'.

\section{(23) koergi ei haugu takka}

FS 'kellelgi pole juhtunuga asja, keegi ei päri juhtunu kohta, juhtunu ei lähe kellelegi korda'

Erinevalt tavatähendusest on kooliõpilaste seletustes sihtmärgiks pigem elus objekt, st kellegi vastu puudub huvi, keegi ei lähe korda sedavõrd, et isegi koer ei haugu ta peale.

'kellestki ei tunta puudust', 'eriti mõttetu mees'

Internetis leiduvad näited käivad tavapäraselt sündmuse kohta, mis on aset leidnud.

Prükkari surma üle ei haugu ka koer. (TOM 2002)

Kas too vald on omaette riik riigis, teevad, mis ise heaks arvavad, koergi ei haugu (politseist rääkimata). (Virumaa Teataja 2005)

(24) elab peost suhu

FS 'vaeselt, tagavaradeta, saadut kohe ära kasutades elama' 
Väljendi tähendus avatakse otseselt, st keskne koht on toidul, mida kas suudetakse ise hankida (a) või saadakse seda teistelt (= teiste käest) (b). Antud väljendi seletuste puhul torkas silma ka teatav filosoofiline käsitlus (täna-homme, olevik-tulevik) (c), mis ülejäänud fraseologismide puhul niivõrd eredalt esile ei tõusnud. Üllataval kombel võib väljendil olla ka positiivne konnotatsioon - keegi ei ela mitte raisates, vaid hoopiski säästes (d):

a) 'mis peos, see kohe söögiks', 'elab vaeselt, raha on ainult toidu jaoks';

b) 'vaene inimene, vara pole, süüa saab, kui teised annavad', 'elab väga vaeselt tänu teiste annetustele', 'tehakse kõik ette-taha ära', 'elab teiste kulul', 'elab teiste almustest';

c) 'elab üks päev korraga ja ei hooli homsest päevast', 'inimene ei planeeri oma tulevikku, vaid teeb nt juhutöid, et ära elada', 'palgapäevast palgapäevani';

d) 'ei saa rahaga priisata', 'kokkuhoidlikult elab'.

Mis on vahepeal toimunud? Suurt midagi, elu nagu ikka: mitte peost suhu, aga peost peoni (soolaleivad, EV aastapäev, kokakursuste lõpetamine jne). (Wordpress.com 2007)

\section{(25) Kas kellaga siga nägid?}

Nagu juba sissejuhatuses sai märgitud, koosneb nimistu eeldatavalt üldtuntud väljenditest, siiski ühe erandiga, milleks on retoorilise küsimuse vormis väljend Kas kellaga siga nägid?, mis on suunatud inimesele, kes ei oska teretada. EKFA andmetel on selle väljendi kasutuse kõrgaeg jäänud küll 19. sajandi lõppu ja 20. sajandi algupoolde, ent viimased fikseeringud pärinevad 1990. aastast. Vähemalt arhiivimaterjali (varaseim Wiedemannilt) põhjal võib järeldada, et tegu on peaasjalikult mandrieestilise levikuga (v.a Jämaja, Mustjalas ja Karjas pelk Oled sa siga näind?) väljendiga. Paraku on aga jäänud mõnevõrra hämaraks väljendis sisalduva kujundi taust. ${ }^{8}$ Adudes, et selle väljendi populaarsus on vajunud minevikku, lülitasin selle ikkagi küsitlusse, lootes saada tõestust oletusele, et väljendit tänapäeval tõepoolest enam ei tunta. Seetõttu ei olnud üllatav tulemus, et väljend liigituski tundmatute kilda. Ent ilmnes huvitav erijoon - Tartu kooliõpilaste seas leidus neid, kes pakkusid omapoolse tõlgenduse. Tähendusversioonid lähtuvad ebahariliku kujundi nn sõnasõnalisest tõlgendamisest, st kellaga siga kui midagi ebaharilikku:

'midagi uskumatut näinu sarkastiliselt solvamine', 'miski võimatu kohta', 'oled sa midagi sellist enne näinud, oled imeasja näinud?', 'ehk paralleel “nagu sadul sea seljas” ehk sobimatu?', 'rikas inimene, aga halb, inimene, kes tahab väga moekas, teistest paremal paista'.

Samas osutab väljendi nagu sadul sea seljas kasutamine tähenduseseletusena assotsiatiivsetele seostele - sadul sea seljas kui midagi sobimatut või mõeldamatut, sama kellaga sea puhul.

8 Väljendi kasutamise ja kujunditekke kohta võib lähemalt lugeda Anne Hussari artiklist (2002). 


\section{Kokkuvõte}

Kuigi fraseologismidele on iseloomulik eelkõige püsivus - millele osutavad juba nimetused püsiväljend, püsiütlus jmt - ei ole see omadus, mis välistaks igasuguse muutumise, ning seda nii leksikaalses kui semantilises plaanis. Teadupärast võivad fraseologismide kaks iseloomulikku tunnust - idiomaatilisus ja motiveeritus - olla erinevate väljendite juures eri kaaluga, ning keelekasutajale valmistavad tõelist raskust just kõrge idiomaatilisuseastmega ühendid. Gümnasistide hulgas katsena tehtud küsitlus näitas, et fraseologismi võidakse selle mittetundmise korral püüda siiski n-ö lahendada ning sõltuvalt väljendi motiveerituse astmest ei pruugi seletus olla sugugi nn tavatähendusest kaugeleminev.

Selliste teistsuguste tõlgenduste esikolmiku osas on kokkulangevus vaid ühe väljendi osas, milleks oli must kass on vahelt läbi jooksnud, kaks ülejäänut on: KG-l lõngagi katki ei vea villast ja ega mu suu pole seinapragu, MHG-l nagu hobuse unenägu ja pane või hambad varna. Suurima erinevusena torkas silma asjaolu, et Tartu kooliõpilased kaldusid tundmatu fraseologismi puhul esitama ka oletusi, omapoolseid tähendusversioone.

Küsitlust üldjoontes kokku võttes võib väita, et valitud traditsioonilisteks peetavad väljendid osutusid täiesti “elavateks” ka tänaste noorte seas, kuna esitatud väljenditest tunti kõiki (küll ühe erandiga). Kindlasti oleks tulemus olnud teistsugune, kui väljendid oleksid esitatud kontekstis. See oleks aga mõjunud pigem etteütlemisena, iseäranis kui sooviks on välja selgitada arusaamist fraseologismi ülekantusest.

Paljude väljendite puhul toimunud semantilised nihkumised - iseäranis huvipakkuvana mõlemas koolis ühtede ja samade väljendite puhul - tekitavad mitmeid küsimusi. Nimelt, kas võiks järeldada, et aja jooksul on toimunud tähenduse teisenemine? Ning kas seda tendentsi võiks üldistada kogu fraseoloogiaalase teadmuse kohta? Läbi viidud küsitluse põhjal söandaks väita, et see teadmus on küll olemas, ent on mingil määral muutunud.

Siinkohal sobiks kasutada sotsiaalpsühholoogiast pärinevat terminit mitmetähenduslikkuse tolerants ${ }^{9}$ ning kohandada seda ka fraseologismide mõistmisele/ mõtestamisele. Nagu küsitlusest ilmnes, käivitub väljendi mittetundmise korral ikkagi selles sisalduva kujundi otsene (või sõnasõnaline) tõlgendamine, ning kuigi selle tulemus on (äärmiselt) ebatõenäoline elik reaalsusele mittevastav, ei heideta seda kõrvale kui sobimatut. Siinkohal on oluline silmas pidada ka tõsiasja, et ei ole olemas üht ja ainust nn õiget tõlgendust, vaid neid võib olla mitu. ${ }^{10}$

Tõenäoliselt on mõistlik käsitleda fraseologismi tähendust avaramana kui seda on tema fikseeritud tavatähendus sõnaraamatus või andmebaasis. Selline arusaam annaks ka aluse suhtuda fraseoloogiliste väljendite mänglevasse kasutusse sallivalt. Hetkeseisuga on küll paraku rohkem küsimusi kui üheseid vastuseid, ent edasiseks uurimistegevuseks on sissejuhatus tehtud.

9 Selle mõistega tähistatakse võimet aktseptida erinevat, teistsugust, vasturääkivat. Omadust peetakse ühtlasi indiviidi kultuurilise kompetentsi eelduseks. Termin on väga levinud saksakeelses kultuuriruumis keeleõppe didaktika alal. Vt ka http://de.wikipedia.org/wiki/Ambiguitätstoleranz (24.09.2007).

10 Seda seisukohta on väljendanud fraseologismide puhul Harald Burger (2003: 56 jj), kes oma käsiraamatus peatub lähemalt mõistel komponentide vaba tähendus ning mõtestab seda kui fraseologismi koosseisu kuuluvate sõnade esinemist polüseemsetena vabas kasutuses. 


\section{Keelenäidete allikad}

Auto24 2006. http://www.auto24.ee/foorum/foorum.php?tid=72214\&last_page=1 (24.04.2007).

Delfi 2007. http://www.delfi.ee/archive/article.php?id=15547934\&categoryID (24.09.2007).

Delfi.blog 2006. http://blog.delfi.ee/node/3256 (24.09.2007).

Diplomaatia 2005. http://www.diplomaatia.ee/est/artikkel.php?id=13 (24.09.2007).

EESS = Loog, Mai. Esimene eesti slängi sõnaraamat. http://www.eki.ee/dict/slang (24.09.2007).

EKFA = Baran, Anneli; Hussar, Anne; Õim, Asta; Õim, Katre. Eesti kõnekäändude ja fraseologismide andmebaas. http://www.folklore.ee/justkui/index.html (1.04.2007).

EPL 2007. http://www.epl.ee/?uudised=376311 (24.09.2007).

Freetime 2007. http://maasikad.ee/Helbreath/phpBB/viewtopic.php?t=24289\&sid=bbc8 1280650131b74e464b196e15989c (24.09.2007).

Kesknädal 2002. http://www.kesknadal.ee/index.php?aid=1769 (24.09.2007).

Kesknädal 2007. http://www.kesknadal.ee/?aid=741 (20.04.2007).

Palts 2005. http://www.palts.ee/index.php?id=1107 (20.04.2007).

Pere ja Kodu 2007. http://www.perekodu.ee/21415 (20.04.2007).

Postimehe kommentaarikeskus 2004. http://www.postimees.ee/010704/kommentaarikeskus.php?ARTIKKEL_ID=138208\&TASK=KOMMENTAARID (20.04.2007).

Postimehe kommentaarikeskus 2007. http://riigikogu.postimees.ee/online/riigikogu2007/ kommentaarikeskus.php?ARTIKKEL_ID=250998\&TASK=KOMMENTAARID (24.09.2007).

Saabnet 2006. http://saabnet.ee/foorum/viewthread.php?fid=11\&tid=2064\&action=print able (24.09.2007).

Streetrace 2007. http://www.streetrace.org/foorum/viewtopic.php?p=693150\&sid=7908eaa ce54d1482ce6170d13f43c6d8 (24.09.2007).

TOM - täna otsustan mina 2002. https://www.eesti.ee/tom/ideas.py/show?idea_id=1467 (24.09.2007).

Ussipesa 2005. http://ussipesa.blogspot.com/2005_05_01_archive.html (24.09.2007).

Virumaa Teataja 2005. http://www.virumaateataja.ee/290605/kommentaarikeskus.php? ARTIKKEL_ID=15025010\&TASK=KOMMENTAARID (24.09.2007).

Wordpress 2007. http://mademoiselleparis.wordpress.com/2007/03/ (20.04.2007).

\section{Kirjandus}

Baran, Anneli 1999. Kõnekäänud ja fraseoloogia - distinktsiooni võimalikkusest / vajalikkusest. - Lohetapja. Pro folkloristica VI. Tartu: Eesti Kirjandusmuuseum, 20-24.

Baur, Rupprecht S.; Chlosta, Christoph 1994. Kennen Kinder heute noch Sprichwörter? Überlegungen zur Altersgrenze in Arbeiten zur empirishen Parömiologie. - C. Chlosta, P. Grzybek, E. Piirainen (Hrsg.). Sprachbilder zwischen Theorie und Praxis. Akten des Westfälischen Arbeitskreises "Phraseologie/Parömiologie" (1991/1992). Studien zur Phraseologie und Parömiologie 2. Bochum: Universitätsverlag Dr. N. Brockmeyer, $1-30$.

Burger, Harald 2003. Phraseologie. Ein Einführung am Beispiel des Deutschen. 2., überarbeitete Auflage. Grundlagen der Germanistik. Berlin: Erich Schmidt Verlag.

Dobrovolski, Dmitri 1997. Idiome in kognitiver Perspektive. Zur Begriffsbestimmung. M. Skog-Södersved (Hrsg.). Ethische Konzepte und mentale Kulturen 1. Auf der Suche nach ethischen Konzepten in Wortschatz und Phraseologie. Acta Universitatis Umensis, Umea Studies in the Humanities 139. Umeå, 17-57.

EKSS $=$ Eesti kirjakeele seletussõnaraamat. I-VII. Tallinn: Eesti Keele Sihtasutus, 19882007. 
Farø, Ken 2006. Ikonographie, Ikonizität und Ikonizismus: Drei Begriffe und ihre Bedeutung für die Phraseologieforschung. http://www.linguistik-online.de/27_06/faroe.html (24.09.2007).

Farø, Ken; Hallsteinsdóttir, Erla 2006. Neue theoretische und methodische Ansätze in der Phraselogieforschung. http://www.linguistik-online.de/27_o6/einleitung.html (24.09.2007).

Filatkina, Natalia 2005. Phraseologie des Letzebuergeschen: Empirische Untersuchungen zu strukturellen, sematisch-pragmatischen und bildlichen Aspekte. Dissertation. Germanistische Bibliothek Bd. 22. Heidelberg: Universitätsverlag Winter.

FS = Õim, Asta 2000. Fraseoloogiasõnaraamat. Tallinn: Eesti Keele Sihtasutus.

Gibbs, Raymond W. Jr. 1989. Understanding and literal meaning. - Cognitive Science 13, 243-251.

Giora, Rachel 2003. On Our Mind: Salience, Context, and Figurative Language. Oxford: Oxford University Press.

Hussar, Anne 2002. Kas kellaga siga nägid? - Oma Keel 1, 15-20.

Jenenšek, Vida 2006. Phraseologie und Fremdsprachenlernen. Zur Problematik einer angemessenen phraseodidaktischen Umsetzung. http://www.linguistik-online.de/27_06/ jerensek.html (24.09.2007).

Krikmann, Arvo 1997. 100 tuntumat eesti kõnekäändu. - A. Krikmann. Sissevaateid folkloori lühivormidesse. 1: põhimõisteid, žanrisuhteid, üldprobleeme. Võrguteaviku URL http://www.folklore.ee/ kriku/LEX/LOENG4.HTM (20.09.2007).

Krikmann, Arvo (toim.) 2004. Koestler, Raskin, Attardo ja teised: lingvistiliste huumoriteooriate uuemaist arenguist. Reetor 4. Tartu: EKM, EKFK.

Lakoff, Georg 1990. Women, Fire and Dangerous Things: What Categories Reveal about the Mind. Chicago-London: University of Chicago Press.

Lakoff, Georg; Johnson, Mark 2003. Metaphors we Live by. Chicago-London: University of Chicago Press.

Roos, Eckhard 2001. Idiom und Idiomatik. Ein sprachliches Phänomen im Lichte der kognitiven Linguistik und Gestalttheorie. Aachen: Shaker.

Röhrich, Lutz 1973. Lexikon der sprichwörtlichen Redensarten. Freiburg: Herder.

Õim, Katre 2004. Fraseologism versus kõnekäänd. - M. Erelt, M-M. Sepper (toim.). Emakeele Seltsi aastaraamat 50 (2003). Tallinn: Emakeele Selts, 129-142.

Wierzbicka, Anna 1999. Emotions Across Languages and Cultures: Diversity and Universals. Studies in Emotion and Social Interaction. Cambridge: Cambridge University Press.

Wikipedia. http://de.wikipedia.org/wiki (24.09.2007).

Anneli Baran (Eesti Kirjandusmuuseum) on lõpetanud Tartu Ülikooli eesti ja soome-ugri filoloogia erialal. Kaitses magistrikraadi Tartu Ülikoolis 1999. a eesti keele fraseoloogia alal, alates 2003. a doktorant eesti ja võrdleva rahvaluule osakonnas. On uurinud eesti fraseologismide semantikat ja struktuuri, fraseoloogia üldteooriat.

anneli@folklore.ee 


\title{
ON THE SEMANTIC AMBIGUITY OF PHRASEOLOGISMS
}

\author{
Anneli Baran \\ Estonian Literary Museum University of Tartu
}

Similarly to the constantly developing lexicon of a language, phraseology, which is closely interrelated with lexicology, is in constant progress. While an important characteristic of phraseologisms is their stability, indicated already by terms like 'set phrases', 'fixed expressions', etc. - this is not a quality that would rule out any kind of change, either on the lexical or the semantic level. It is generally known that the two characteristic features of phraseologisms - idiomaticity and motivation - may be of varying significance depending on the nature of a phrase, and a language user may find utterances of high level of idiomaticity particularly challenging. Problems with understanding phraseologisms are mostly discussed in relation with non-ethnic speakers. However, a questionnaire on the knowledge of phraseologisms, distributed among the secondary level students in two Estonian(-language) schools, revealed that phrases presumed to be commonly known - more or less idiomatic phraseologisms - may not be so for the younger generation of language users. The analysis of results shows that there have been certain changes in the conceptualisation and use of phraseologisms, and these changes are mostly associated with either the misunderstanding of the indirect meaning of a phrase, i.e., direct interpretation, or the misinterpretation based on associations of the phrase's key word.

Keywords: semantics, phraseology, expressions, questionnaire, Estonian language 